\title{
Kontribusi Sumber Belajar dan Internal Locus of Controll Terhadap Hasil Belajar Mata Pelajaran Produk Kreatif Dan Kewirausahaan
}

\author{
Andi Mulia ${ }^{*}$, Wakhinuddin² iD \\ ${ }^{1,2}$ Jurusan Pendidikan Teknologi Kejuruan, Universitas Negeri Padang, Sumatera Barat, Indonesia \\ *Corresponding author: andimulia@gmail.com
}

\begin{abstract}
Abstrak
Penelitian ini bertujuan untuk menganalisis kontribusi sumber belajar terhadap hasil belajar, kontribusi Internal Locus of Controll terhadap hasil belajar, serta kontribusi sumber belajar dan Internal Locus of Controll secara bersama-sama terhadap hasil belajar. Jenis penelitian adalah deskriptif korelasional, populasi penelitian adalah semua siswa kelas XI di SMK sebanyak 77. Penelitian ini menetapkan kelas XI TBSM 1 dan kelas XI TBSM 2 sebagai sampel yaitu sebanyak 51 orang siswa, dan kelas Uji coba kelas XI TBSM 3. Instrumen pengumpulan data menggunakan kuisioner menggunakan Skala Likert, teknik analisis data diantaranya regresi sederhana dan regresi berganda. Hasil penelitian menunjukkan bahwa internal locus of controll berkontribusi terhadap hasil belajar sebesar 33,41\%; sumber belajar berkontribusi terhadap hasil belajar sebesar $31,36 \%$ serta sumber belajar dan internal locus of controll berkontribusi secara bersama-sama terhadap hasil belajar sebesar $40,83 \%$. Hasil penelitian dapat disimpulkan bahwa sumber belajar dan internal locus of controll secara bersama-sama memberikan kontribusi terhadap hasil belajar siswa kelas XI mata pelajaran simulasi komunikasi digital di SMK.
\end{abstract}

Kata kunci: Sumber Belajar, Internal Locus of Controll , Hasil Belajar

\section{Abstract}

This study aims to analyze the contribution of learning resources to learning outcomes, the contribution of the Internal Locus of Controll to learning outcomes, as well as the contribution of learning resources and the Internal Locus of Controll together on learning outcomes. This type of research is descriptive correlational, the research population is all students of class XI in SMK as many as 77. This study determines class XI TBSM 1 and class XI TBSM 2 as a sample, namely 51 students, and class Trial class XI TBSM 3. Data collection instruments using a questionnaire using a Likert scale, data analysis techniques including simple regression and multiple regression. The results showed that the internal locus of control contributed to learning outcomes by $33.41 \%$; learning resources contributed $31.36 \%$ to learning outcomes and learning resources and internal locus of controll contributed together to learning outcomes by $40.83 \%$. The results of the study can be concluded that the learning resources and internal locus of control together contribute to the learning outcomes of class XI students in digital communication simulation subjects at SMK.

Keywords: Learning Resources, Internal Locus of Controll , Learning Outcomes

\author{
History: \\ Received : 20 November 2020 \\ Revised : 5 Desember 2020 \\ Accepted : 14 Februari 2021 \\ Published : 25 Maret 2021
}

Publisher: Undiksha Press

Licensed: This work is licensed under

a Creative Commons Attribution 4.0 License

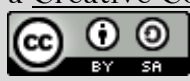

\section{Pendahuluan}

Pendidikan memiliki penanan penting dalam membentuk sumber daya manusia menjadi lebih baik dan berkualitas dalam menunjang pembangunan nasional. Tujuan utama pendidikan adalah mengembangkan potensi yang dimiliki agar menjadi manusia yang lebih baik (Puspitasari, 2019; Sudarsana, 2016). Pendidikan yang baik diberbagai bidang, akan 
menghasilkan sumber daya manusia yang berkualitas, kreatif, inovatif untuk menghadapi berbagai masalah dimasa yang akan dating (Khairat, 2020). Meningkatkan sumber daya manusia dapat melalui mata pelajaran Produk Kreatif dan Kewirausahaan. Mata pelajaran produk kreatif dan kewirausahaan diharapkan dapat memberikan pengetahuan dan keterampilan lebih kepada siswa tentang kewirausahaan, selain itu diharapkan dapat menumbuhkan minat siswa dalam berwirausaha (Khotimah et al., 2020).

Kenyataannya berdasarkan data yang peroleh pada kelas XI SMKN 1 Sintoga Padang Pariaman hasil belajar pada Mata pelajaran Produk Kreatif Dan Kewirausahaan masih banyak di bawah KKM. Hal ini dapat dilihat dari peroleh nilai ujian tengah semester I tahun 2020/2021.

Tabel 1. Rekapitulasi Nilai MID Siswa Kelas XI TBSM SMK Negeri 1 Sintog

\begin{tabular}{cccccccc}
\hline \multirow{2}{*}{ Kelas } & \multirow{2}{*}{$\begin{array}{c}\text { Jumlah } \\
\text { (Siswa) }\end{array}$} & $\begin{array}{c}\text { Rata-Rata } \\
\text { Pengetahuan }\end{array}$ & $\begin{array}{c}\text { Rata-Rata } \\
\text { Keterampilan }\end{array}$ & \multicolumn{2}{c}{ Pengetahuan } & \multicolumn{2}{c}{ Keterampilan } \\
\hline XI TB SM 1 & 26 & 73.17 & 71.63 & 15 & 11 & 14 & 12 \\
XI TB SM 1 & 25 & 68.19 & 70.19 & 10 & 15 & 12 & 13 \\
XI TB SM 1 & 26 & 66.83 & 69.83 & 11 & 15 & 12 & 14 \\
\hline
\end{tabular}

Berdasarkan Tabel 1. di atas, dapat diketahui bahwa tingkat ketuntasan siswa untuk Mata pelajaran produk kreatif dan kewirausahaan masih ada yang belum tuntas baik dari pengetahuan dan keterampilan. Hal ini berarti beberapa siswa yang belum tuntas pada mata pelajaran produk kreatif dan kewirausahaan di kelas XI TBSM SMK Negeri 1 Sintoga Kabupaten Padang Pariaman. Keberhasilan dalam peningkatan mutu pendidikan dilihat dari hasil belajar siswa (Harni, 2021). Hasil belajar merupakan tolak ukur untuk menentukan tingkat keberhasilan siswa dalam mengetahui dan memahami suatu mata pelajaran yang dinyatakan dengan nilai yang berupa huruf atau angka (Herwanto, 2020). Hasil belajar siswa adalah kemampuan yang diperoleh siswa setelah melalui kegiatan belajar (Susanto, 2013). Tinggi rendahnya hasil belajar siswa dipengaruhi oleh faktor internal maupun eksternal. Salah satu faktor yang mempengaruhi hasil belajar yaitu sumber belajar. Sumber belajar merupakan hal penting untuk diperhatikan dalam memahami mata pelajaran Mata pelajaran produk kreatif dan kewirausahaan. Sumber belajar merupakan semua sumber baik berupa data, orang dan wujud tertentu yang dapat digunakan oleh siswa dalam belajar, baik secara terpisah maupun secara terkombinasi sehingga mempermudah siswa dalam mencapai tujuan kompetensi tertentu (Fatimaturrahmi, 2018). Sumber belajar memberikan pengaruh terhadap hasil belajar (Fitriani et al., 2019)

Penyebab rendahnya hasil belajar siswa yang lain adalah dari diri siswa, rendahnya kendali diri siswa dalam belajar (Sulistyaningrum et al., 2018). Hal ini juga dipengaruhi oleh persepsi siswa tentang siapa yang berhak menentukan keberhasilan dalam hidupnya. Karakteristik siswa yang berpengaruh dalam proses belajar yaitu locus of control (Afriadi \& Yuni, 2018). Internal locus of controll adalah cara dimana seseorang yakin control terhadap peristiwa berasal dari kemampuannya (Dewita, 2018). Internal locus of controll sebagai tingkat dimana individu yakin bahwa mereka dalah penentu nasib mereka sendiri (Fauzan, 2020). Selain itu, individu yang memiliki internal locus of controll memahami bahwa hasil yang diperolehnya tergantung pada seberapa banyak usaha yang dilakukannya. Keyakinan akan kemampuan dan usaha mendorongnya untuk bekerja keras, memiliki inisiatif untuk melakukan hal yang baru secara mandiri. Individu ini juga akan mampu berpikir efektif untuk mengatasi masalah dan percaya bahwa usaha harus dilakukan jika ingin mencapai kerberhasilan (Putri \& Rustika, 2019).

Sejalan dengan temuan beberapa penelitian, menemukan bahwa terdapat pengaruh signifikan sumber belajar dalam keluarga terhadap hasil belajar (Siregar et al., 2015). 
Internal locus of controll berpengaruh signifikan terhadap hasil belajar (Anggraini, 2020). Hasil belajar siswa yang memiliki locus of internal lebih tinggi (Sinaga, Amran Jahot \& Harun Sitompul, 2017). Internal locus of controll berpengaruh signifikan terhadap hasil belajar (Trisnawati, Sya Bachri Thalib, 2018). Kelompok siswa yang memiliki locus of controll internal memperoleh hasil belajar IPA yang lebih tinggi dibandingkan kelompok siswa yang memiliki locus of controll eksternal (Afriadi \& Yuni, 2018).

Berdasarkan hasil penelitian relevan diatas dapat disimpulkan bahwa terdapat beberapa faktor yang mempengaruhi hasil belajar siswa, diantaranya adalah motivasi belajar, minat belajar, sumber belajar dan locus of controll. Namun pada penelitian ini hanya dibatasi pada kontribusi sumber belajar dan internal locus of controll terhadap hasil belajar. Penelitian ini bertujuan untuk mengetahui kontribusi kontribusi sumber belajar dan internal locus of controll terhadap hasil belajar mata pelajaran produk kreatif dan kewirausahaan.

\section{Metode}

Penelitian ini dilakukan dengan menggunakan rancangan"ex post facto" dengan pendekatan korelasional. Arikunto (2013:313) menjelaskan bahwa deskriptif korelasional merupakan suatu penelitian yang dirancang untuk menentukan tingkat hubungan variabelvariabel yang berbeda dalam suatu populasi. Variabel dalam penelitian ini terdiri dari sumber belajar sebagai variabel bebas, internal locus of controll sebagai variabel bebas dan hasil belajar sebagai variabel terikat. Gambar variabel penelitian dapat dilihat pada tabel 1. Populasi penelitian ini adalah siswa kelas XI TBSM SMKN 1 Sintoga Padang Pariaman yang terdiri dari 3 kelas dengan jumlah 77 orang siswa. Teknik pengambilan sampel dalam penelitian ini adalah purposif sampling. Penelitian ini menetapkan kelas XI TBSM 1 dan kelas XI TBSM 2 sebagai sampel yaitu sebanyak 51 orang siswa, dan kelas Uji coba kelas XI TBSM 3. Sumber data yang digunakan dalam penelitian ini yaitu data primer merupakan data yang secara langsung didapat dari hasil penyebaran angket kepada responden, yaitu siswa. Instrumen yang digunakan dalam penelitian yaitu angket dengan menggunakan skala likert.

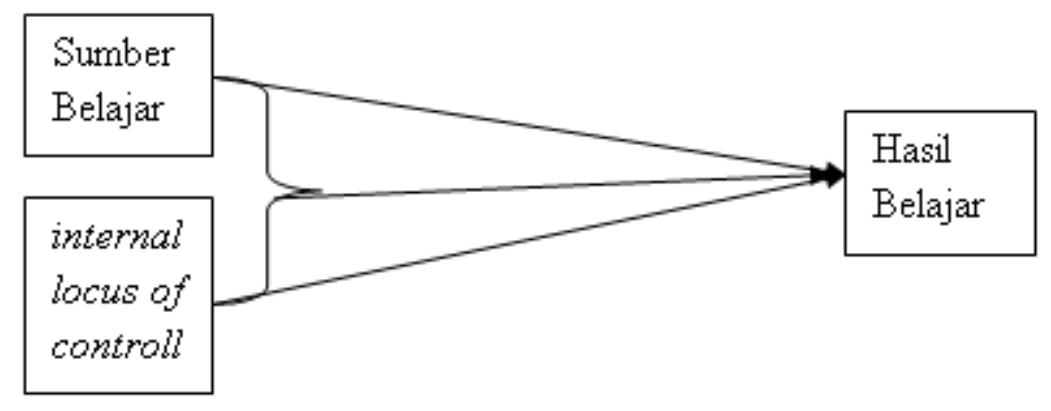

Gambar 1. Variabel terikat

Teknik analisis data yang digunakan yaitu (1) deskripsi data yaitu skor mean (nilai rerata), median, modus, dan standar deviasi. (2) pengujian persyaratan analisis yaitu uji normalitas, uji homogenitas, uji linearitas dan pengujian independensi veriabel bebas. (3) Hipotesis menggunakan korelasi sederhana, regresi sederhana dan korelasi berganda.

\section{Hasil dan Pembahasan}

Hasil penelitiannya dapat dilakukan pendeskripsian data, uji asumsi klasik terlebih dahulu yang meliputi uji normalitas, uji linerarti dan uji homogenitas. Data yang dipaparkan dalam penelitian ini adalah data hasil sumber belajar dan internal locus of control sebagai 
variabel bebas $(\mathrm{X})$ dan hasil belajar sebagai variabel terikat $(\mathrm{Y})$. Data sumber yang dijadilkan sampel dalam penelitian sebanyak 51 siswa. Sebelum melakukan analisis uji hipotesis, terlebih dahulu dilakukan uji asumsi diantara, uji normalita, uji homogenitas, dan uji linearitas. Uji normalitas yang digunakan dalam penelitian ini adalah suatu uji untuk melihat residual sebaran data yang dimiliki berasal dari sebaran normal atau tidaknya yaitu menggunakan teknik Komogorov Smirnov dengan menetapkan taraf signifikan 5\% atau $\alpha=$ 0,05. Data dapat dikatakan berdistribusi normal jika taraf signifikan (Asymp.Sig) $>0,05$ maka data berdistribusi normal, hasil pemeriksaan dapat dilihat pada Tabel 2. di bawah ini:

Sebelum melakukan pengujian hipotesis, dapat dilakukan pendeskripsian data, uji asumsi klasik terlebih dahulu yang meliputi uji normalitas, uji linerarti dan uji homogenitas. Data yang dipaparkan dalam penelitian ini adalah data hasil sumber belajar dan internal locus of control sebagai variabel bebas (X) dan hasil belajar sebagai variabel terikat (Y). Data sumber yang dijadilkan sampel dalam penelitian sebanyak 51 siswa. Berdasarkan hasil analisis data menunjukkan bahwa frekuensi skor yang paling tinggi pada variabel sumber belajar yaitu di rentang $80-83$ sebanyak $25,49 \%$. 17,65\% dari skor sumber belajar berada pada kelas interval skor rata-rata, $45,10 \%$ skor sumber belajar di atas rata-rata dan 37,25\% berada dibawah skor rata-rata. Hal ini berarti bahwa sebagian besar skor sumber belajar berada di atas kelas interval skor rata-rata. Rata-rata sumber belajar yaitu 78,37. Sedangkan hasil analisis data untuk varibel internal locus of controll ditemukan bahwa frekuensi yang paling tinggi terletak pada rentang 73-79 dengan frekuensi sebesar 25,49\%. Rata-rata internal locus of controll sebesar 79,82. 21,57\% dari skor internal locus of controll berada pada kelas interval skor rata-rata, 33,33\% skor internal locus of controll di atas rata-rata dan $45,10 \%$ berada dibawah skor rata-rata. Hal ini berarti bahwa sebagian besar skor internal locus of controll berada di bawah kelas interval skor rata-rata.

Sebelum melakukan analisis uji hipotesis, terlebih dahulu dilakukan uji asumsi diantara, uji normalita, uji homogenitas, dan uji linearitas. Uji normalitas yang digunakan dalam penelitian ini adalah suatu uji untuk melihat residual sebaran data yang dimiliki berasal dari sebaran normal atau tidaknya yaitu menggunakan teknik Komogorov Smirnov dengan menetapkan taraf signifikan 5\% atau $\alpha=0,05$. Data dapat dikatakan berdistribusi normal jika taraf signifikan (Asymp.Sig) > 0,05 maka data berdistribusi normal, hasil pemeriksaan dapat dilihat pada Tabel 2.

Tabel 2. Hasil Uji Normalitas dengan Test Kolmogrov Smirnov

\begin{tabular}{cccc}
\hline \multicolumn{1}{c}{ Uji K-S } & $\begin{array}{c}\text { Hasil } \\
\text { Belajar }\end{array}$ & Internal Locus of Control & Sumber Belajar \\
\hline Kolmogorov-Smirnov Z & 0.682 & 0.757 & 0.628 \\
$\rho=$ asym sig nilainya & 0.742 & 0.615 & 0.825 \\
\hline
\end{tabular}

Berdasarkan Tabel 2. terlihat bahwa hasil uji normalitas tersebut dapat dinyatakan data yang digunakan dalam penelitian ini telah berdistribusi normal dan bisa dilanjutkan untuk diteliti lebih lanjut, karena nilai signifikan dari uji normalitas > 0,05. Untuk homogenitas dilakukan dengan menggunakan uji chi kuadrat $\chi^{2}$. Kriteria yang digunakan adalah jika $\chi^{2}$ hitung dengan $\mathrm{p}>0,05$, maka varian kelompok adalah homogen. Dengan demikian persyaratan homogenitas untuk analisis regresi terpenuhi.

Tabel 3. Hasil Uji Homogenitas

\begin{tabular}{clcc}
\hline No & \multicolumn{1}{c}{ Variabel } & Asym.sig & Keterangan \\
\hline 1 & Hasil Belajar & 0,595 & Homogen \\
2 & Internal Locus of Control & 0,978 & Homogen \\
\hline
\end{tabular}


Uji linearitas dilakukan untuk mengetahui apakah dua variabel mempunyai hubungan yang linear atau tidak signifikan dan juga sebagai persyaratan dalam analisis korelasi atau regresi, apabila taraf signifikan antara dua variabel kurang dari 0,05 maka dikatakan mempunyai hubungan yang linear

Tabel 4. Hasil Uji Linearitas

\begin{tabular}{lcc}
\hline \multicolumn{1}{c}{ Variabel } & Signifikan & Keterangan \\
\hline Sumber Belajar & 0.060 & Homogen \\
Internal Locus of Control & 0.824 & Homogen \\
\hline
\end{tabular}

Berdasarkan Tabel 4. dapat dijelaskan bahwa nilai signifikan pada linearitas sumber belajar dan internal locus of control terhadap hasil belajar lebih besar dari 0,05 maka dapat disimpulkan bahwa antara variabel sumber belajar dan internal locus of control terhadap hasil belajar terdapat hubungan yang linear. Pengujian hipotesis dapat dilakukan apabila telah memenuhi ketiga uji asumsi telah dilakukan. Uji hipotesis dilakukan dengan menggunakan teknik analisis korelasi dan regresi sederhana untuk menguji hipotesis 1 dan 2 dan analisis korelasi dan regresi berganda untuk menguji hipotesis 3. Berdasarkan hasil penelitan maka dapat rangkum pada Tabel 5.

Tabel 5. Hasil Analisis Korelasi Sederhana dan Korelasai Berganda

\begin{tabular}{ccccc}
\hline Korelasi & Koefisien Korelasi $(\mathbf{R})$ & $\begin{array}{c}\text { Korefisien Dererminasi } \\
\left(\mathbf{R}^{\mathbf{2}}\right)\end{array}$ & Kontribusi & $\rho$ \\
\hline $\operatorname{Ryx}_{1}$ & 0,560 & 0,3136 & $31,36 \%$ & 0,000 \\
$\operatorname{Ryx}_{2}$ & 0,578 & 0,3341 & $33,41 \%$ & 0,000 \\
$\operatorname{ryx}_{1} x_{2}$ & 0,639 & 0,4083 & $40,83 \%$ & 0,000 \\
\hline
\end{tabular}

Hasil perhitungan pada Tabel 5. menunjukkan bahwa koefsien korelasi $\left(\mathrm{ryx}_{1}\right)=0,560$ dengan $\rho=0,000<\alpha=0,05$. Ini berarti bahwa terdapat hubungan yang signifikan antara sumber belajar dengan hasil belajar pada kategori cukup kuat. Besarnya koefisien determinasi $\left(\mathrm{r}^{2}\right)$ sebesar 0,3136. Untuk mengetahui bentuk hubungan prediktif atau tidak antara sumber belajar dan hasil belajar, dilakukan analisis regresi sederhana. Sesuai dengan hasil analisis diperoleh persamaan regresi $\hat{Y}=12,823+0,648 X_{1}$. Selanjutnya dilakukan uji keberartian keofisien regresi. Rangkuman hasil analisisi dapat dilihat pada Tabel 6.

Tabel 6. Hasil Uji Koefisien Regresi Sumber Belajar terhadap Hasil belajar

\begin{tabular}{lccc}
\hline \multicolumn{1}{c}{ Sumber } & Koefisien & t & Sig \\
\hline Konstanta & 12.823 & 1.192 & 0.239 \\
Sumber Belajar & 0.648 & 4.736 & 0.000 \\
\hline
\end{tabular}

Hipotesis kedua sesuai dengan hasil perhitungan diperoleh koefsien korelasi $\left(\mathrm{ryx}_{2}\right)=$ 0,578 dengan $\rho=0,000<\alpha=0,05$. Ini berarti bahwa terdapat hubungan yang signifikan antara internal locus of control dengan hasil belajar pada kategori cukup kuat. Besarnya koefisien determinasi $\left(\mathrm{r}^{2}\right)$ sebesar 0,3341 . Untuk mengetahui bentuk hubungan prediktif atau tidak antara internal locus of control dan hasil belajar, dilakukan analisis regresi sederhana. Sesuai dengan hasil analisis diperoleh persamaan regresi $\hat{Y}=31,678+0,4006 \mathrm{X}_{2}$. Selanjutnya 
dilakukan uji keberartian keofisien regresi. Rangkuman hasil analisisi dapat dilihat pada Tabel 7.

Tabel 7. Hasil Uji Koefisien Regresi Internal Locus of Control terhadap Hasil Belajar

\begin{tabular}{lccc}
\multicolumn{1}{c}{ Sumber } & Koefisien & t & Sig \\
\hline Konstanta & 31.678 & 8.954 & 0.000 \\
Internal Locus of Control & 0.400 & 6.409 & 0.000 \\
\hline
\end{tabular}

Hipotesis ketiga diperoleh koefsien korelasi $\left(\operatorname{ryx}_{1} x_{2}\right)=0,666$ dengan $\rho=0,000<$ $\alpha=0,05$. Dengan demikian dapat dinyatakan bahwa terdapat hubungan yang sangat signifikan antara internal locus of control dan sumber belajar secara bersama-sama dengan hasil belajar Mata pelajaran produk kreatif dan kewirausahaan siswa kelas XI TBSM SMKN 1 Sintoga Padang Pariaman adalah sebesar 40,83\%.

Untuk mengetahui bentuk hubungan prediktif atau tidak antara internal locus of control dan sumber belajar terhadap hasil belajar, dilakukan analisis regresi berganda dan dapat persamaan regres $\hat{Y}=12,089+0,263 \mathrm{X}_{1}+0,389 \mathrm{X}_{2}$. Rangkuman hasil analisisi dapat dilihat pada Tabel 8.

Tabel 8. Rangkuman Hasil Uji Koefisien Regresi Internal Locus of Control dan Sumber Belajar

\begin{tabular}{lccc}
\hline \multicolumn{1}{c}{ Sumber } & Koefisien & T & Sig \\
\hline Konstanta & 12.089 & 1.198 & 0.237 \\
Sumber Belajar & 0.389 & 2.455 & 0.018 \\
Internal Locus of Control & 0.263 & 2.773 & 0.008 \\
\hline
\end{tabular}

Berdasarkan hasil penelitian sumber belajar memberikan kontribusi terhadap hasil belajar. Hal ini dikarenakan penggunaan sumber belajar berupa internet dan buku memudahkan siswa untuk mencari berbagai pengetahuan baru selain yang disampaikan guru dalam pembelajaran di kelas. Siswa dapat mencari dan menemukan semua informasi yang mereka butuhkan terkait materi pelajaran di berbagai tempat dan berbagai kesempatan sehingga tidak terbatas pada ruang kelas dan guru. Pemilihan serta penggunaan sumber belajar yang cocok dan baik, maka kemungkinan mampu meningkatkan hasil belajar siswa (Sudjana, 2009).

Internal locus of control memberikan pengaruh terhadap hasil belajar karna didukung oleh faktor-faktor yang mempengaruhi prestasi belajar pelajaran produk kreatif dan kewirausahaan yaitu faktor dari dalam atau faktor intern, salah satunya adalah locus of control. Siswa yang memiliki locus kendali internal cenderung mempunyai sifat yang lebih aktif dalam mencari, mengolah, dan memanfaatkan berbagai informasi, serta memiliki keinginan mencapai prestasi yang lebih tinggi. Siswa yang memiliki lokus kendali internal memiliki rasa percaya diri lebih tinggi, memiliki kemauan bekerja keras, dan memiliki kekhawatiran akan gagal. Internal locus of control merupakan keyakinan seseorang bahwa didalam dirinya tersimpan potensi besar untuk menentukan nasip sendiri (Nainggolan et al., 2018).

Banyak temuan penelitian yang berkaitan dengan sumber belajar dan Internal Locus Of control. Temuan hasil penelitian (Sujai, 2017) menyatakan bahwa pemanfaatan sumber belajar berpengaruh signifikan terhadap prestasi belajar ekonomi. Terdapat pengaruh yang signifikan sumber belajar dalam keluarga terhadap hasil belajar (Siregar et al., 2015). Internal locus of controll berpengaruh signifikan terhadap hasil belajar (Anggraini, 2020). Hasil belajar yang memiliki locus of internal lebih tinggi dan locus of controll eksternal. 
(Trisnawati, Sya Bachri Thalib, 2018) menunjukkan bahwa internal locus of controll berpengaruh signifikan terhadap hasil belajar (Sinaga, Amran Jahot \& Harun Sitompul, 2017). Kelompok siswa yang memiliki locus of controll internal memperoleh hasil belajar IPA yang lebih tinggi dibandingkan kelompok siswa yang memiliki locus of controll eksternal. Internal locus of control, prestasi akademik dan kematangan karier akuntansi(Afriadi \& Yuni, 2018) berpengaruh terhadap kesiapsan siswa Pendidikan Akuntansi untuk bekerja di luar profesi guru (Devi \& Fachrurrozie, 2019).

Hasil penelitian ini memberikan makna yang mendalam bahwa tinggi rendahnya hasil belajar matematika siswa ditentukan oleh sumber belajar dan internal locus of control. Dengan demikian jelas bahwa sumber belajar dan internal locus of control terhadap hasil belajar mata pelajaran produk kreatif dan kewirausahaan. Keterbatan dalam penelitian ini yaitu pada sampel yang digunakan jumlahnya sedikit. Diharapkan untuk penelitian selanjutnya dapat menggunakan sampel yang lebih banyak lagi

\section{Simpulan}

Berdasarkan hasil penelitian dapat disimpulkan bahwa kemampuan argumentasi Berdasarkan hasil analisis data serta pembahasan maka dapat disimpulkan bahwa (1) Sumber belajar memberikan kontribusi yang berarti terhadap hasil belajar Mata pelajaran Produk Kreatif Dan Kewirausahaan siswa kelas XI TBSM SMKN 1 Sintoga Padang Pariaman. (2) Internal locus of control berkontribusi terhadap hasil belajar Mata pelajaran produk kreatif dan kewirausahaan siswa kelas XI TBSM SMKN 1 Sintoga Padang Pariaman. (3) Internal locus of control dan sumber belajar memberikan kontribusi yang secara bersama-sama untuk meningkatkan hasil belajar siswa. Ada kontribusi antara sumber belajar dan internal locus of control terhadap hasil belajar siswa. Hal ini menunjukkan bahwa adanya peranan penting dari sumber belajar dalam meningkatkan hasil belajar. Oleh karena itu orang tua secara idealnya membantu anaknya dengan melenggapi kebutuhan belajar dengan baik seperti penyediaan sumber belajar yang menunjang siswa dalam belajar. Kemudian internal locus of control siswa sangat penting untuk menentukan keberhasilan siswa. Keberhasilan siswa akan sukses jika siswa memiliki keyakinan yang kurat dan berusaha untuk mewujudkannya.

\section{Daftar Rujukan}

Afriadi, R., \& Yuni, R. (2018). Pengaruh Strategi Pembelajaran Learning Cycle dan Locus Of Control Siswa Terhadap Hasil Belajar IPA. Jurnal Biolokus, 1(1), 1-10. http://jurnaltarbiyah.uinsu.ac.id/index.php/biolokus/article/view/312/310.

Anggraini, N. \& M. (2020). Influence Internal Locus of Control, School Environment and Discipline on Student Achievement. The Fifth Padang International Conference On Economics Education, Economics, Business and Management, Accounting and $\begin{array}{lll}\text { Entrepreneurship } \quad \text { (PICEEBA-5 328-333. } & \text { 2020), }\end{array}$ https://doi.org/10.2991/aebmr.k.201126.036.

Devi, B. D. K., \& Fachrurrozie. (2019). Pengaruh Internal Locus of Control, Lingkungan Keluarga, Dan Prestasi Akademik Terhadap Kesiapan Bekerja Di Luar Profesi Guru Melalui Kematangan Karier. Economic Education Analysis Journal, 8(1), 110-129. https://doi.org/10.15294/eeaj.v8i1.29764.

Dewita, M. (2018). Hubungan antara internal locus of control dengan perilaku prososial pada pelajar d SMA N 1 Halmahera Utara. Jurnal Sosial Dan Kependidikan, 2(1), 10-17. http://journal.unhena.ac.id/index.php/HibSos/article/view/42.

Fatimaturrahmi. (2018). Pengaruh Ketersediaan Sumber Belajar Di Perpustakaan Sekolah Terhadap Motivasi Belajar Siswa Pada Mata Pelajaran IPS Terpadu SMP Negeri 1 
Praya Barat. Jurnal Kajian Penelitian \& Pengembangan Pendidikan, 6(6). https://doi.org/10.36312/jisip.v1i2.184.

Fauzan, F. (2020). Pengaruh Soft Skill Dan Locus of Control Terhadap Kesiapan Fresh Graduate Dalam Era Industri 4.0 (Studi Pada Prodi Manajemen Unihaz Bengkulu). Creative Research Management Journal, 2(2), 1. https://doi.org/10.32663/crmj.v2i2.1105.

Fitriani, A. N., Purnomo, A., \& Ginanjar, A. (2019). Pemanfaatan Lingkungan sebagai Sumber Belajar terhadap Hasil Belajar IPS Kelas VII SMP Negeri 2 Ambarawa. SOSIOLIUM, $1(2)$, $164-168$. https://journal.unnes.ac.id/sju/index.php/sosiolium/article/view/36422/15002.

Harni. (2021). Penerapan Model Pembelajaran Inkuiri untuk Meningkatkan Motivasi dan Hasil Belajar Siswa pada Materi Cahaya dan Sifat-Sifatnya di SD Negeri 2 Uebone. Jurnal Paedagogy, 8(2), 181-189. https://doi.org/10.33394/jp.v8i2.3481.

Herwanto, H. (2020). Penggunaan Metode Estafet Learning Terhadap Peningkatan Kemampuan Berpikir Kritis Dan Hasil Belajar Mahasiswa Pada Mata Kuliah Metode Numerik. Edukasi Dan Sains Matematika, 6(1), 11-21. https://journal.uniku.ac.id/index.php/JESMath/article/view/2497/1791.

Khairat, Y. (2020). Penerapan Model Project Based Learning Dalam Meningkatkan Aktifitas Dan Hasil Belajar Peserta Didik Pada Mata Pelajaran Produk Kreatif Dan Kewirausahaan. Jurnal Teknologi Pendidikan, 9(2), 185-196. https://garuda.ristekbrin.go.id/documents/detail/1728761.

Khotimah, P. C., Kantun, S., \& Widodo, J. (2020). Kewirausahaan Terhadap Minat Berwirausaha Siswa Di Smk Negeri 7 Jember ( Studi Kasus Pada Kelas Xii Program Keahlian Multimedia Semester Gasal Tahun Ajaran 2019 / 2020 ). Jurnal Pendidikan Ekonomi, 14(2), 357-360. https://doi.org/10.19184/jpe.v14i2.16522.

Nainggolan, M. ., Kojo, C., \& Sendow, G. (2018). Analisis Pengaruh Internal Locus of Control Dan External Locus of Control Terhadap Kepuasan Kerja Serta Dampaknya Terhadap Kinerja Ratulangi Analysisn of the Effect of Internal Locus of Control and External Locus of Control on Job Satisfaction and Its Imp. Jurnal EMBA, 6(4), 40234032. https://doi.org/10.35794/emba.v6i4.21926.

Puspitasari, S. (2019). Upaya Meningkatkan Hasil Belajar Ipa Dengan Menggunakan Model Pembelajaran Think Pair Share. Global Edukasi, 3(1), 55-60. http://jurnal.goretanpena.com/index.php/JGE.

Putri, N. L. P. N. I. A., \& Rustika, I. M. (2019). Peran pola asuh otoritatif dan internal locus of control terhadap kecerdasan emosional remaja madya di SMA Negeri 1 Tabanan. Jurnal Psikologi Udayana, 6(01), 56. https://doi.org/10.24843/jpu.2019.v06.i01.p06.

Sinaga, Amran Jahot \& Harun Sitompul, S. (2017). Pengaruh Strategi Pembelajaran dan Locus Of Control Terhadap Hasil Belajar Pendidikan Agama Siswa Kelas XI SMA Swasta St. Thomas 2 Medan. JURNAL TABULARASA PPS UNIMED, 14(2), 119128. https://doi.org/10.24114/jt.v14i2.9648.

Siregar, S. M., Tarma, T., \& Doriza, S. (2015). Pengaruh Sumber Belajar Dalam Keluarga Terhadap Hasil Belajar Siswa. JKKP (Jurnal Kesejahteraan Keluarga Dan Pendidikan), 2(2), 31. https://doi.org/10.21009/jkkp.022.06.

Sudarsana, I. K. (2016). Peningkatan mutu pendidikan luar sekolah dalam upayapembangunan sumber daya manusia. Jurnal Penjaminan Mutu, 1(1), 1-14. http://www.ejournal.ihdn.ac.id/index.php/JPM/article/download/34/43.

Sudjana. (2009). Penilaian Hasil Belajar Mengajar. remaja Rosdakarya.

Sujai, I. S. (2017). Pengaruh kesiapan belajar dan pemanfaatan Sumber belajar terhadap prestasi belajar mata pelajaran ekonomi siswa kelas xi ips sma pgri kalangbret 
semester 1 tahun pelajaran 2016/2017. Jurnal Pendidikan Ekonomi, 2(2), 16-25. https://doi.org/10.29100/.v2i2.349.

Sulistyaningrum, H., Kuntum, H., \& Ummatin, K. (2018). Effectiveness Of Problem Solving Of Solso And Locus Of Control Against Mathematics Learning Achievements Of High School Students. Jurnal Teladan, Volume 3(2), 133-141. http://journal.unirow.ac.id/index.php/teladan/article/view/41.

Susanto, A. (2013). Teori Belajar Dan Pembelajaran Di Sekolah Dasar. Kencana Prenada Media Group Algesindo.

Trisnawati, Sya Bachri Thalib, \& R. (2018). Pengaruh Internal Locus of Control Terhadap Motivasi dan Hasil Belajar Biologi Siswa SMA Negeri Di Sinjai Barat. Prosiding Seminar Nasional Biologi Dan Pembelajarannya. https://ojs.unm.ac.id/semnasbio/article/view/7222/0. 